\title{
POTENCY OF PAPAYA SEED POWDER (Carica papaya L.) AS CHICKEN MEAT AND SHRIMP PRESERVATIVE
}

\author{
Nani Radiastuti ${ }^{1 *}$, Gusniar Auvina Berty ${ }^{2}$, Reno Fitri ${ }^{3}$
}

Received : August 11, 2020

Accepted : October 25, 2020

\section{DOI: 10.15575/biodjati.v5i2.9267}

1,2,3 Department of Biology, Faculty of Science and Technology UIN Syarif Hidayatullah, Jakarta, Banten, 15419 Telp. 021-7493606

e-mail:

*1nani.radiastuti@uinjkt.ac.id gusniarauvinaberty97@gmail.com 3reno.fitri@uinjkt.ac.id

*Corresponding author
Abstract. Chicken meat and shrimp are perishable food materials. Giving natural preservatives is one way to extend the storage time of food. This study aimed to know the potential of papaya seed powder varieties of 'Bangkok' and 'California' as preservatives. The sample consisted of two varieties of papaya seed powder with concentrations of 2,4,6 and $8 \mathrm{~g}$. Storage time for chicken meat and shrimp was three days. Parameters measured were total bacterial colonies, pH va-lues, and organoleptic characteristics (color, aroma and texture) of fresh chicken meat and shrimp. The result showed papaya seed powder influences the quality of chicken meat and shrimp. fresh chicken meat and shrimp with papaya seed powder varieties 'Bangkok' and 'California' had a lower total bacterial colony as much as $9 \times 10^{5}$ until $1 \times 10^{6}$ compared to control which were $4.2 \times 10^{7}-1.87$ $x 10^{7}$. Organoleptic result of chicken meat and shrimp with the treatment of papaya seed powder and stored for three days continue to decrease in term of color, aroma and texture. In chicken meat, the decrease in bacterial growth was still within the limits of microorganism contamination quality in animal-based food. However, the same concentrations of papaya seed powder in the shrimp have not been able to reduce bacterial growth until the limit permitted by SNI.

Keywords: 'Bangkok' and 'California' seed, Chicken meat, Organoleptic test, Total plate test count (TPC) Shrimp.

\section{Citation}

Radiastuti, N., Berty, G. A. \& Fitri, R. (2020). Potency of Papaya Seed Powder (Carica papaya L.) as Chicken Meat and Shrimp Preservative. Jurnal Biodjati, 5(2), 281-293.

\section{INTRODUCTION}

Chicken meat and Vaname shrimp are easily-damaged food because of its high protein contains. Meat damage is largely influenced by sanitation at the slaughterhouse, during transportation, marketing, and during the meat storage. Thus good handling is important to maintain the quality of chicken and shrimp when they arrived at consumers. The short shrimp durability is affected by the high water content of shrimp that reaching
76.14\% (Suradi, 2016; Ahmad et al., 2018). The presence of microorganisms can cause damage, rottenness, and produce unpleasant odors (Winarno, 2007). One way to extend the storage time of food by providing preservatives. Providing preservatives is a method used to extend the storage time of fresh meat and other meat products (Soeparno, 2011). Food preservatives can be classified into two; first, natural preservatives obtained from natural material such as red galangal extract (Alpina purpurata) against the durability 


\section{JURNAL BIDDJATI}

http://journal.uinsgd.ac.id/index.php/biodjati

of chicken meat, extract of betel leaf (Piper betle) and bay leaf (Syzgium polyanthum) as an alternative to tofu preservatives. The second group is synthetic preservatives such as acetic acid, benzoic acid, and sorbic acid (Kharisma, 2013).

The weakness of synthetic preservatives is a side effect that appeared. Synthesis preservatives are believed to cause negative effects on health such as cancer cell growth caused by carcinogenic compounds in preservative. So, awareness of preservatives food using natural ingredients began to increase as it believed to besafe for consumption (Susanto et al., 2011).

Research on the use of natural material as a preservative in fish has been carried out by various researchers including the use of Aloe vera as a natural material in preserving fresh milkfish (Agustini et al., 2007). Research related to papaya seed powder as a preservative has been conducted by Salim et al. (2018), he proved that the use of papaya seed powder (unknown variety) at a concentration of $4 \%$ has antibacterial characteristic against fresh shrimp because it can reduce the $\mathrm{pH}$ and the total colony of fresh shrimp bacteria. The total bacterial colonies in the fresh shrimp have not met the national standard (SNI 7388:2009) in terms of the quality limit of microorganism contamination in animal-based food material $\left(5 \times 10^{5} \mathrm{CFU} / \mathrm{g}\right)$. According to Peter et al. (2014) papaya seed extract from several concentrations has the potential to inhibit the growth of Staphylococcus aureus, Pseudonomonas aeruginosa, Escherichia coli, and Salmonella typhi. Papaya seed contains tannin, phenol, saponin and flavonoid compound. Tanin has the ability to inhibit bacterial growth (Taufiq et al., 2015). Therefore research applications of papaya seed powder need to be studied further, especially applications in other fresh foods with different varieties.
The research was conducted using papaya seed 'Bangkok' and 'California' varieties. These two varieties can be obtained easily and consumed by many people. This research was the first step to find out the length of storage of chicken meat and shrimp that was given papaya seed powder. Moreover, it showed the quality and organoleptic characteristic of fresh chicken meat and shrimp after giving papaya seed powder varieties 'California' and 'Bangkok' with storage duration of one and three days at $4{ }^{\circ} \mathrm{C}$.

\section{MATERIALS AND METHODS}

This research used papaya seeds from different varieties, namely the Bangkok papaya variety that was obtained from a plantation in Sukabumi, and the California variety that was obtained from a plantation in Bogor. The samples were taken in June 2019.

\section{Papaya Seed Powder of 'Bangkok' and 'California' Varieties}

Papaya seed sample of $100 \mathrm{~g}$ was dried using the wind dry method for five days. Sample of papaya seeds that have been dried was then crushed by a blender to obtain papaya seed sample in the form refined powder so that it is more soluble in water. Seed powder was then filtered by siever 200 mesh (Masduqi et al., 2014).

\section{Preservation of Chicken Meat and Shrimp}

Chicken meat and shrimp samples obtained from the sampling location were immediately packed and put in zipped plastic to maintain the cleanliness of fresh chicken meat and shrimp. The samples were taken to the laboratory to be treated by papaya seed powder varieties of 'Bangkok and California'. The papaya seed powder in the concentrations of 0 , $2,4,6$, and $8 \mathrm{~g}$ was sprinkled to $100 \mathrm{~g}$ of fresh 


\section{JURNAL BIDDJATI}

http://journal.uinsgd.ac.id/index.php/biodjati

chicken meat and shrimp (without removing the skin). The fresh chicken meat and shrimp were then put in a zipped plastic and stored for three days at a cold temperature $\left(4^{\circ} \mathrm{C}\right)$.

\section{Analysis of Plate Count Agar (PCA) SNI 01-2332-3-2006}

Chicken meat and shrimp samples were weighed aseptically (SNI 7388:2009) as much as $25 \mathrm{~g}$. The samples were then put into a sterile plastic containing $225 \mathrm{~mL} 0.98 \% \mathrm{NaCl}$ solution and were homogenized. The result of homogenates was then diluted using serial dilution method by dissolving $1 \mathrm{~mL}$ of sample solution into $9 \mathrm{~mL}$ of sterile $\mathrm{NaCl}$, until $10^{-6}$ dilution. The dilutions of $10^{-4}, 10^{-5}, 10^{-6}$ were made into two series. As much as $1 \mathrm{~mL}$ of solution from each dilution was put into a different sterile PCA in the petri dish. Cultures were incubated in an upside-down cup position for 48 hours at $37^{\circ} \mathrm{C}$. Total Plate Count (TPC) testing was carried out on the first and third days.

\section{Calculation Total Plate Number (ALT)}

Calculation was counted conventionally by using a colony counter. Colonies $<25$ were not counted whereas colony with $25-250$ colonies were counted by using the formula (SNI 01-2332.3, 2006):

$$
\mathrm{N}=\frac{\sum C}{[(1 \times n 1)+(0,1 \times n 2)] x(d)}
$$

$\mathrm{N}=$ number of colony product ( colony per $\mathrm{g}$ ); $\sum \mathrm{C}=$ number of colony in all plates counted; $\mathrm{n} 1=$ number of plates in the first dilution that are counted;

$\mathrm{n} 2=$ number of plates in the second dilution that are counted;

$\mathrm{d}=$ the first dilution that is counted.

\section{pH Measurement}

$\mathrm{pH}$ measurements were carried out by using a $\mathrm{pH}$ meter. The $\mathrm{pH}$ meter was previously calibrated by using a buffer solution of pH 4 and buffer pH 7 (BSN, 2009).

\section{Organoleptic Analysis}

The organoleptic analysis was refered to BSN 3924: 2009 in accordance with the organoleptic test sheet score determined by the national standardization agency. In organoleptic testing, data were collected with the assessment sheet (score sheet). Things that were tested including color, aroma, and texture. The raw samples were presented and the panelist were asked to rate them according to their preference level with the addition of a comparative sample without treatment. There were 25 untrained panelists in each organoleptic test. The hedonic test were performed on the first day and third days with the same 25 panelists. The organoleptic test was conducted to determine the acceptance of panelists preference level for the treatment of papaya seed powder on chicken meat and shrimp with the following evaluation criteria: ( $1=$ really dislike), $(2=$ dislike $),(3=$ neutral $),(4=$ likes $)$, and $(5=$ really like).

\section{Data Analysis}

The TPC, $\mathrm{pH}$, and organoleptic test data were analyzed using ANOVA (analysis of variance) to determine the effect of each treatment. If the effect of the treatment was significantly different with a confidence level of $95 \%$, a further Tukey test was carried out.

\section{RESULTS AND DISCUSSION}

\section{Average Total Plate Count (TPC) Value of Chicken Meat and Shrimp}

The microbiological quality of chicken meat and shrimp can be determined by a large number of microorganisms in chicken meat and shrimp. Calculation of total bacterial colo- 


\section{JURNAL BIDDJATI}

http://journal.uinsgd.ac.id/index.php/biodjati

nies was carried out to determine the ability of papaya seed powder to inhibit bacterial growth in chicken meat and shrimp. The maximum limit of the total number of bacterial colonies in animal-based food material as stated in SNI 7388:2009 are 1x10 $10^{6} \mathrm{CFU} / \mathrm{g}$ for chicken meat and $5 \times 10^{5} \mathrm{CFU} / \mathrm{g}$ (SNI, 2009) for shrimp. If the bacterial content in chicken meat and shrimp exceeds the specified standard, then they are unsuitable for consumption as food as their quality decrease and may cause disease. The results showed that the number of bacteria cell in chicken meat and shrimp treated with papaya seed powder varieties of 'Bangkok' or 'California' (Table 1) was decline compared to control.

Table 1. The average TPC value of chicken meat and shrimp treated with papaya seeds powder varieties 'Bangkok' and 'California'

\begin{tabular}{|c|c|c|c|c|c|c|c|c|}
\hline \multirow{2}{*}{$\begin{array}{c}\text { Treat- } \\
\text { ment } \\
\text { chicken } \\
\text { meat }(\mathrm{g})\end{array}$} & \multicolumn{8}{|c|}{ Storage time (days) } \\
\hline & $\begin{array}{c}\mathrm{TPC} \\
(\mathrm{CFU} / \mathrm{g})\end{array}$ & $\begin{array}{c}\text { Standard } \\
\text { Devia- } \\
\text { tion }\end{array}$ & $\begin{array}{c}\mathrm{TPC} \\
(\mathrm{CFU} / \mathrm{g})\end{array}$ & $\begin{array}{c}\text { Standard } \\
\text { Devia- } \\
\text { tion }\end{array}$ & $\begin{array}{c}\text { TPC } \\
\text { (CFU/g) }\end{array}$ & $\begin{array}{c}\text { Standard } \\
\text { Devia- } \\
\text { tion }\end{array}$ & $\begin{array}{c}\text { TPC } \\
(\mathrm{CFU} / \mathrm{g})\end{array}$ & $\begin{array}{c}\text { Standard } \\
\text { Devia- } \\
\text { tion }\end{array}$ \\
\hline & \multicolumn{2}{|c|}{1 (day) } & \multicolumn{2}{|c|}{3 (days) } & \multicolumn{2}{|c|}{1 (day) } & \multicolumn{2}{|c|}{3 (days) } \\
\hline \multirow[t]{2}{*}{ Control } & $1 \times 10^{6}$ & 0.44 & $4.2 \times 10^{7}$ & 0.46 & $1.72 \times 10^{6}$ & 0.5 & $1.87 \times 10^{7}$ & 0.5 \\
\hline & \multicolumn{4}{|c|}{ Bangkok } & \multicolumn{4}{|c|}{ California } \\
\hline 2 & $5.3 \times 10^{5}$ & 0.32 & $8.2 \times 10^{6}$ & 0.35 & $1.44 \times 10^{6}$ & 0.23 & $1.06 \times 10^{7}$ & 0.24 \\
\hline 4 & $1.2 \times 10^{6}$ & 0.02 & $1.5 \times 10^{6}$ & 0.02 & $1.22 \times 10^{6}$ & 0.01 & $1.44 \times 10^{6}$ & 0.02 \\
\hline 6 & $6.4 \times 10^{5 *}$ & 0.07 & $1.2 \times 10^{6 *}$ & 0.08 & $2.9 \times 10^{5 *}$ & 0.14 & $1 \times 10^{6 *}$ & 0.15 \\
\hline 8 & $4.5 \times 10^{5 *}$ & 0.08 & $9 \times 10^{5 *}$ & 0.08 & $3.5 \times 10^{5^{*}}$ & 0.12 & $1 \times 10^{6 *}$ & 0.13 \\
\hline \multirow{3}{*}{$\begin{array}{l}\text { Treat- } \\
\text { ment } \\
\text { shrimp } \\
(\mathrm{g}) \\
\end{array}$} & \multicolumn{8}{|c|}{ Storage time (day) } \\
\hline & $\begin{array}{c}\text { TPC } \\
(\mathrm{CFU} / \mathrm{g})\end{array}$ & $\begin{array}{c}\text { Standard } \\
\text { Devia- } \\
\text { tion }\end{array}$ & $\begin{array}{c}\mathrm{TPC} \\
(\mathrm{CFU} / \mathrm{g})\end{array}$ & $\begin{array}{c}\text { Standard } \\
\text { Devia- } \\
\text { tion }\end{array}$ & $\begin{array}{c}\text { TPC } \\
(\mathrm{CFU} / \mathrm{g})\end{array}$ & $\begin{array}{c}\text { Standard } \\
\text { Devia- } \\
\text { tion }\end{array}$ & $\begin{array}{c}\text { TPC } \\
(\mathrm{CFU} / \mathrm{g})\end{array}$ & $\begin{array}{c}\text { Standard } \\
\text { Devia- } \\
\text { tion } \\
\end{array}$ \\
\hline & \multicolumn{2}{|c|}{1 (day) } & \multicolumn{2}{|c|}{3 (days) } & \multicolumn{2}{|c|}{1 (day) } & \multicolumn{2}{|c|}{3 (days) } \\
\hline \multirow[t]{2}{*}{ Control } & $2 \times 10^{5}$ & 0.98 & $4.3 \times 10^{8}$ & 0.1 & $6.3 \times 10^{5}$ & 0.37 & $1.45 \times 10^{7}$ & 0.38 \\
\hline & \multicolumn{4}{|c|}{ Bangkok } & \multicolumn{4}{|c|}{ California } \\
\hline 2 & $2.3 \times 10^{5}$ & 0.85 & $3 \times 10^{7}$ & 0.86 & $5.8 \times 10^{5}$ & 0.35 & $1.15 \times 10^{7}$ & 0.36 \\
\hline 4 & $2 \times 10^{5}$ & 0.52 & $1.6 \times 10^{7}$ & 0.53 & $3.1 \times 10^{5}$ & 0.46 & $1.56 \times 10^{7}$ & 0.47 \\
\hline 6 & $1.6 \times 10^{5 *}$ & 0.18 & $7.8 \times 10^{5 *}$ & 0.19 & $3.9 \times 10^{5^{*}}$ & 0.48 & $2.25 \times 10^{7 *}$ & 0.48 \\
\hline 8 & $1.3 \times 10^{5 *}$ & 0.18 & $6.1 \times 10^{5 *}$ & 0.18 & $2.7 \times 10^{5 *}$ & 0.49 & $1.75 \times 10^{7 *}$ & 0.5 \\
\hline
\end{tabular}

Statistical analysis result showed significant difference in papaya seed powder treatment in different concentration and storage time to the number of bacterial cells in chicken meat compared to control $(\mathrm{p}<0.05)$. This shows that papaya seed powder has the ability to inhibit bacterial growth.

The result showed that giving papaya seed powder as much as $8 \mathrm{~g}$ has a very significant effect on the number of chicken meat bacterial cells, compared to the control. This Radiastuti et al. is because papaya seed powder contains several antibacterial compounds such as flavonoids that are able to inhibit bacterial growth. The flavonoids contains phenol called carbolic acid which has an acid characteristic. The structure of cell walls and cytoplasm of bacterial consist of proteins and fats. The presence of antibacterial compounds such as flavonoids can denature proteins and damage cell membranes. Papaya seed powder 'Bangkok' variety is more effective than 'California' variety, 


\section{JURNAL BIDDJATI}

http://journal.uinsgd.ac.id/index.php/biodjati

because by the concentration of $2 \mathrm{~g}$. It can reduce bacterial concentration $\left(8.2 \times 10^{6}\right)$ under control (Table 1 ).

Treatment of papaya seed powder to shrimp at different concentrations and storage time was significantly affected the number of bacterial cells compared to controls $(\mathrm{p}<0.05)$, which means that papaya seed powder has the ability to inhibit the growth of different bacteria in each concentration. Storage time also affected the number of bacterial cells in shrimp significantly compared to control. The treatment of papaya seed powder as much as 8 $\mathrm{g}$ affected significantly the bacterial cell number compared to controls. This is because papaya seed powder has content that can inhibit the growth of microorganisms. That is in accordance with the opinion of Cahyadi (2008), the antimicrobial character of formaldehyde is the result of its ability to inactivate proteins into hydrocolloids. Treatment of papaya seed powder 'Bangkok' or 'California' variety as much as 2, 4, 6, and $8 \mathrm{~g}$ on first day and on third day resulted in the decreasing number of bacterial cells. The higher the administration of papaya seed powder to the shrimp, the lower the number of bacteria obtained.

Salim et al. (2018) reported that soaking of papaya seed extract as much as 2, 4, and $6 \%$ for two hours can increase storability of shrimp for 12 days storage time. According to Peter et al. (2014) papaya seed extract with concentrations of $2.5,5,7.5$, and $10 \%$ have the potential to inhibit the growth of Staphylococcus aureus, Pseudomonas aeruginosa, Eschehrichia coli, Salmonella typhi.

TPC values increase during storage because bacterial growth begins to increase since the shrimp die. The shrimp temperature rises, causing bacteria to attack immediately. After tissue damage occurs in the body of the shrimp, there will be changes in the composi- tion of the meat that resulting in decay (Salim et al., 2018). According to Suparno (2012), decay in shrimp is caused by the presence of blood vessels and dirt in the shrimp's head. Shrimp undergoes autolysis of fats and proteins very fast, and black spots arise on the treatment carried out in high temperatures. According to Suradi (2005), microbial activity during storage produces alkali compounds. The strong alkali caused by the decomposition of chemical compounds especially proteins, so that the decomposition process will continue to increase.

Several studies related to the use of bioactive compounds as antibacterial have been carried out. soaking papaya seed extracts on the storability of shrimp as much as 2, 4 and $6 \%$ for two hours has a storage time of 12 days (Salim et al., 2018). Papaya seeds have antibacterial effects that useful for curing chronic skin diseases, such as ektima. Papaya seeds also have antibacterial activity against Trichomonas vaginalis. Papaya seed powder contains fatty acid bioactive compounds that have the ability to inhibit bacterial growth.

According to research of Torar et al. (2017), papaya seeds has antibacterial activity because it contains alkaloids (Carpaine) which can inhibit bacterial growth. Carpaine is a lactonate ringed alkaloid with seven groups of methylene chains so it is effective to inhibit the activity of several microorganisms. Carpaine can digest microorganisms proteins and turn them into derivatives compound called peptones. Papaya seeds also contain another compound such as flavonoids. Flavonoids are polyphenol compounds that are widespread in nature, based on chemical structure flavonoid compounds consist of flavonol, flavon, flavonoid catechin, anthocyanidins, and chalcons (Taufiq et al., 2015).

Papaya seeds powder contains tannin which tends to have the highest bioactive 


\section{JURNAL BIDDJATI}

http://journal.uinsgd.ac.id/index.php/biodjati

compounds content value among the phenol compound, saponins, and flavonoids. Tanin generally has a bland taste and more acidic, this causes the papaya seeds to have a bitter taste. Tannins have the ability to inhibit bacterial growth (Salim et al., 2018). Tannins have the character of wrinkles membranes cell. The action mechanism of tannin as an antibacterial is to inhibit the reverse transcriptase enzyme so that bacterial cells cannot be formed.

\section{pH Value of Chicken Meat and Shrimp}

Microbiological quality of chicken meat and shrimp is one of the parameters in looking at the quality and damage level to chicken meat and shrimp. Microbiological quality of chicken meat and shrimp can be selected from changes in physical and chemical quality including $\mathrm{pH}$ value and organoleptic properties (color, aroma, and texture). The $\mathrm{pH}$ value is one of the important parameters that affect the growth of bacteria and other microorganisms.

The initial $\mathrm{pH}$ value in both chicken meat samples treated by papaya powder 'Bangkok' and 'California' varieties showed a neutral $\mathrm{pH}$ (7) and remained neutral (6.6 7.2) after three days of storage (Table 2). The $\mathrm{pH}$ measured in this study was classified as neutral pH. According to Suradi (2008) reported that chickens before slaughter have a $\mathrm{pH}$ value of 6.51 and then declined to 5.96 and 5.82 at the time of 10 hours and 12 hours after slaughter at room temperatures. The $\mathrm{pH}$ value obtained in this study until the $12^{\text {th }}$ hour was still in accordance with the initial $\mathrm{pH}$ value of chicken meat. Data shows that the higher $\mathrm{pH}$ level of papaya seed powder 'Bangkok' and 'California' varieties in chicken meat causes the $\mathrm{pH}$ value increase (Table 2). This is because papaya seed powder has a $\mathrm{pH}$ value of 7 (neutral), so papaya seed powder affected the chicken meat $\mathrm{pH}$ value.

Table 2. The $\mathrm{pH}$ value of chicken meat and shrimp treated with papaya seed powder varieties 'Bangkok' and 'California'

\begin{tabular}{|c|c|c|c|c|c|c|c|c|}
\hline \multirow{2}{*}{$\begin{array}{l}\text { Treatment } \\
\text { chicken } \\
\text { meat }(\mathrm{gr})\end{array}$} & \multicolumn{8}{|c|}{ Storage time (days) } \\
\hline & $\mathrm{pH}$ & $\begin{array}{c}\text { Standard } \\
\text { Deviation }\end{array}$ & $\mathrm{pH}$ & $\begin{array}{c}\text { Standard } \\
\text { Deviation }\end{array}$ & $\mathrm{pH}$ & $\begin{array}{l}\text { Standard } \\
\text { Deviation }\end{array}$ & $\mathrm{pH}$ & $\begin{array}{l}\text { Standard } \\
\text { Deviation }\end{array}$ \\
\hline & \multicolumn{2}{|c|}{1 (day) } & \multicolumn{2}{|c|}{3 (days) } & \multicolumn{2}{|c|}{1 (day) } & \multicolumn{2}{|c|}{3 (days) } \\
\hline \multirow[t]{2}{*}{ Control } & 7 & 0.21 & 6.23 & 0.22 & 7 & 0.1 & 6.6 & 0.11 \\
\hline & \multicolumn{4}{|c|}{ Bangkok } & \multicolumn{4}{|c|}{ California } \\
\hline 2 & 7 & 0.1 & 6.62 & 0.11 & 7 & 0.1 & 6.62 & 0.11 \\
\hline 4 & 7 & 0.02 & 6.92 & 3 & 7 & 0.05 & 6.81 & 0.06 \\
\hline 6 & 7 & 0 & 7 & 0 & 7 & 0.5 & 7.22 & 0.06 \\
\hline 8 & 7 & 0 & 7 & 0 & 7 & 0.05 & 7.24 & 0.06 \\
\hline \multirow{3}{*}{$\begin{array}{l}\text { Treatment } \\
\text { shrimp (gr) }\end{array}$} & \multicolumn{8}{|c|}{ Storage time (days) } \\
\hline & $\mathrm{pH}$ & $\begin{array}{c}\text { Standard } \\
\text { Deviation }\end{array}$ & $\mathrm{pH}$ & $\begin{array}{c}\text { Standard } \\
\text { Deviation }\end{array}$ & $\mathrm{pH}$ & $\begin{array}{l}\text { Standard } \\
\text { Deviation }\end{array}$ & $\mathrm{pH}$ & $\begin{array}{l}\text { Standard } \\
\text { Deviation }\end{array}$ \\
\hline & \multicolumn{2}{|c|}{1 (day) } & \multicolumn{2}{|c|}{3 (days) } & \multicolumn{2}{|c|}{1 (day) } & \multicolumn{2}{|c|}{3 (days) } \\
\hline \multirow[t]{2}{*}{ Control } & 7 & 0.46 & 8.72 & 0.47 & 7 & 0.52 & 8.94 & 0.52 \\
\hline & \multicolumn{4}{|c|}{ Bangkok } & \multicolumn{4}{|c|}{ California } \\
\hline 2 & 7 & 0.41 & 8.53 & 0.41 & 7 & 0.41 & 8.53 & 0.42 \\
\hline 4 & 7 & 0.41 & 8.51 & 0.41 & 7 & 0.41 & 8.52 & 0.42 \\
\hline 6 & 7 & 0.35 & 8.33 & 0.36 & 7 & 0.41 & 8.51 & 0.42 \\
\hline 8 & 7 & 0.32 & 8.21 & 0.33 & 7 & 0.41 & 8.5 & 0.42 \\
\hline
\end{tabular}




\section{JURNAL BIDDJATI}

http://journal.uinsgd.ac.id/index.php/biodjati

The initial $\mathrm{pH}$ value of both shrimp samples treated with papaya seed powder 'Bangkok' and 'California' varieties showed a neutral $\mathrm{pH}$ (7). After three days of storage the $\mathrm{pH}$ value increased to the alkali $(8.2-$ 8.9) (Table 2). The $\mathrm{pH}$ value continues to increase during storage due to the degradation of proteins that will produce simpler nitrogen compounds such as the free amino acids and nitrogen alkali acid. The addition of nitrogen alkali will increase $\mathrm{pH}$. According to Suradi (2005), the activity of microorganisms during storage results in the decomposition of chemical compounds. Especially proteins that produce alkali compounds and strong alkali, so that the decomposition process will be followed by an addition in $\mathrm{pH}$.

A decrease in $\mathrm{pH}$ due to long storage will cause the water holding capacity to decrease. This is in accordance with the opinion of Soeparno (2009) which stated that the difference in the holding capacity of water is also partly due to the rate and magnitude of the decrease in $\mathrm{pH}$. This is reinforced by the statement of Bahar (2003) which states that the holding capacity of water is influenced by the rate and magnitude of the $\mathrm{pH}$ value. The lower the $\mathrm{pH}$, the lower the holding capacity of water to meat. According to Salim et al. (2018), the treatment of papaya seed powder shows a slower $\mathrm{pH}$ change because papaya seed powder binds to the binding capacity of water.

\section{Chicken and Shrimp Organoleptic Value}

Organoleptic testing of chicken meat and shrimp greatly determines its quality. The fresh meat products are chewy and if we pressed with a finger the scar will return soon. Meat that undergoes a decay process will become physically damaged, lose its texture, and watery. According to Torar et al. (2017) for shrimp, the condition of the body segment or leg segment usually determine the freshness level of a segmented fishery product. The fresh condition fishery product such as a kind of shrimp is characterized by the complete limbs that are still attached and the strength of the attached limbs.

From The organoleptic test, it is obtained that organoleptic value experienced decreasees after longer storage time. The results of analysis of variance showed that treatment of papaya seed powder Bangkok and California varieties to chicken meat with a storage time of three days was significantly different $(p<0.05)$ on color, aroma and texture compared to control. Duncan's further test result showed that the treatment of papaya seed powder at a concentration of $2 \mathrm{~g}$ was produced the color, aroma, and texture of chicken meat that was very favorably compared to the concentration of 4,6 , and $8 \mathrm{~g}$.

The color, aroma, and texture of chicken meat treated by papaya seed powder as much as 4,6 , and $8 \mathrm{~g}$ were less favorable with scoring of less than 3 . It means that the panelists did not like the color in the treatment of papaya seed powder. This is because the result obtained from organoleptic testing based on the level of preference of the panelists which have paler color compare to fresh chicken meat which has a fresh aroma like papaya seed powder.

Organoleptic test obtained showed that low organoleptic values resulted from experience a decrease in color, aroma, and texture caused by a longer storage time. However,the texture has a good level of preference with a scoring of 3 . It means panelists like the texture of chicken meat that has a hard texture compared to meat control chicken (Figure 1, $2,3 \& 4)$ 
Jurnal Biodjati 5(2):281-293, November 2020

\section{JURNAL BI@DJATI}

http://journal.uinsgd.ac.id/index.php/biodjati

\section{Chicken Meat}

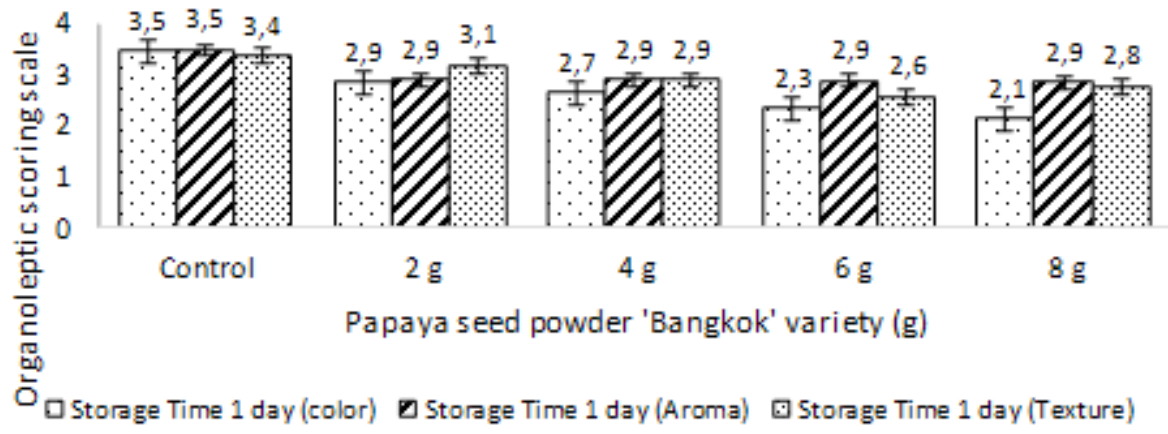

Figure 1. Organoleptic of papaya seed powder variety of 'Bangkok' in chicken meat for one day of storage

\section{Chicken Meat}

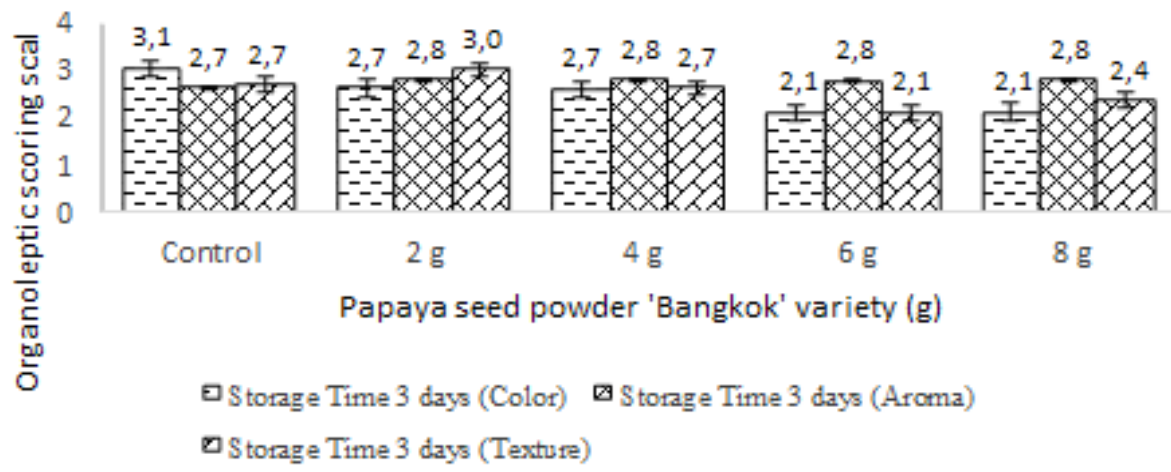

Figure 2. Organoleptic of papaya seed powder variety of 'Bangkok' in chicken meat for three day of storage

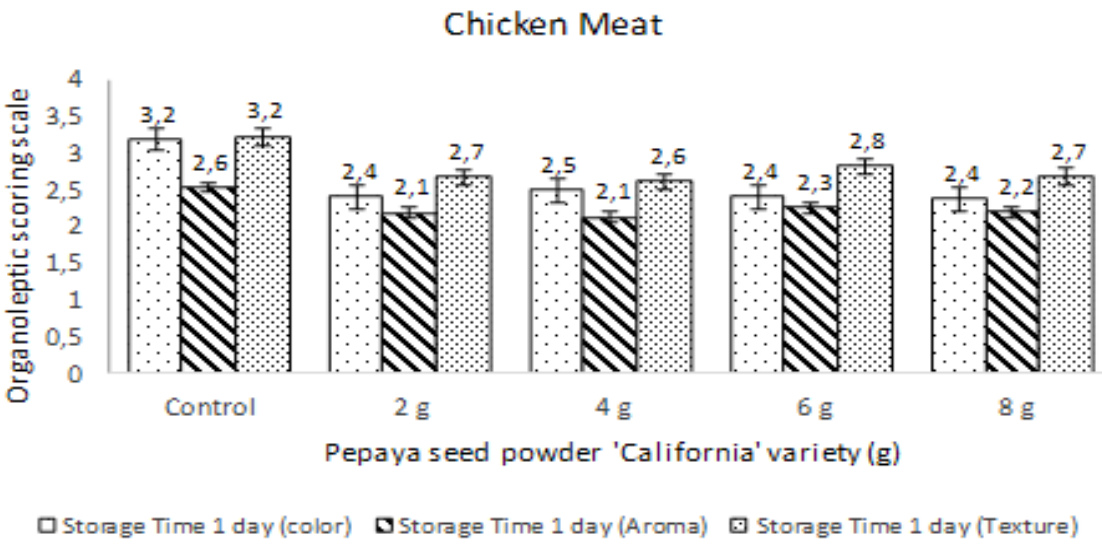

Figure 3. Organoleptic of papaya seed powder variety of 'California' on chicken meat for one day of storage 


\section{JURNAL BIDDJATI}

http://journal.uinsgd.ac.id/index.php/biodjati

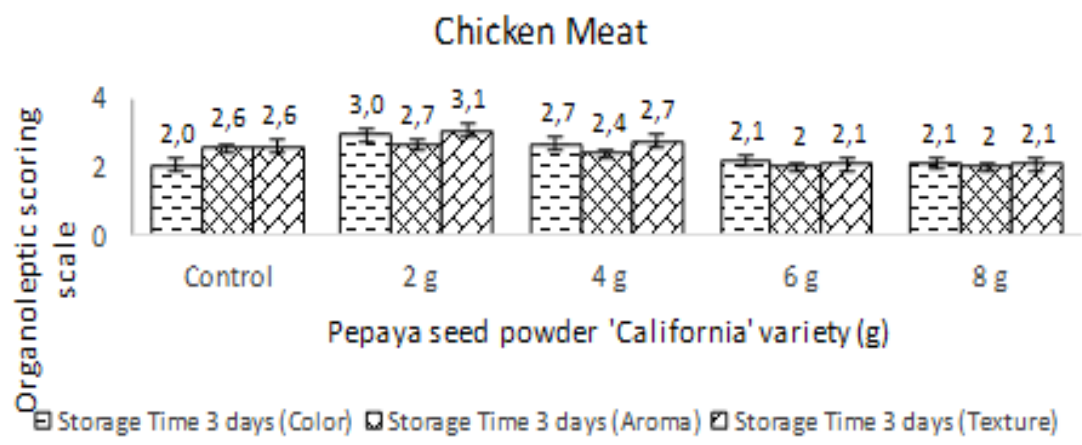

Figure 4. Organoleptic of papaya seed powder variety of 'California' in chicken meat for three days of storage

Unlike the treatment of papaya seed powder which has a stable decrease in value during storage, a decrease in organoleptic appearance shows that there is decay during storage. Based on the research by Rajesh (2008) stated that changes in the texture of food material during storage can be caused by changes in water content which affects the hardness of food material (getting softer).

The main components affecting meat hardness are connective tissue, meat fiber, and fat (Aberle et al., 2001). According to Fellows (1992), the texture of the meat is also affected by the type, moisture content, and the number of structural carbohydrates and protein. Texture changes are caused by fat loss, emulsion damage, hydrolysis from carbohydrate polymers, coagulation and protein hydrolysis, as well as the temperature level of the environment and the meat itself. Sitindoan (2007) found that the meat age also influences the hardness level. Old meat has more rough muscle fiber compare to young meat as older meat binds more water which can affect the texture of the meat.

Variance analysis results revealed that a provision of papaya seed powder variety Bangkok on shrimp with storage of thee days was significantly preferred $(\mathrm{p}<0.05)$ in terms of color, aroma, and texture compared to shrimp control. Duncan's further test result showed that treatment of provision papaya Jurnal Biodjati 5(2):281-293, November 2020 seed powder at concentration of 2, 4, 6, and 8 $\mathrm{g}$, was significantly favored in terms of color, aroma, and texture of shrimp compared to control. The color as well as aroma and texture of shrimp treated by papaya seed powder Bangkok variety with a concentration of $2 \mathrm{~g}$ received an assessment of 3 , which means that panelists liked the color, aroma and texture of shrimp even after three days of storage. This is because shrimp did not have pale color, fishy aroma, but has a hard texture. The results were similar with organoleptic shrimp with the treatment of papaya seed powder California variety.

Results of analysis of variance showed that giving papaya seed powder California variety on the shrimp with three days storage time was significantly preferred $(p<0.05)$ in terms of color, aroma, and texture compared to control. Duncan's further test results showed that the treatment of giving papaya seed powder at concentrations of 2, 4, 6, and 8 g were significantly preferred compare to control. The color, as well as aroma and texture of shrimp by treatment of papaya seed powder in a concentration of $2 \mathrm{~g}$ were more favorable than a concentration 4,6 , and $8 \mathrm{~g}$. The higher concentration of papaya seed powder results in the harder the texture and the paler the color. The addition of papaya seed powder to shrimp can reduce the $\mathrm{pH}$ value of shrimpthus causing color changes (Figure 5, 6, $7 \& 8$ ). 
Jurnal Biodjati 5(2):281-293, November 2020

\section{JURNAL BI@DJATI}

http://journal.uinsgd.ac.id/index.php/biodjati

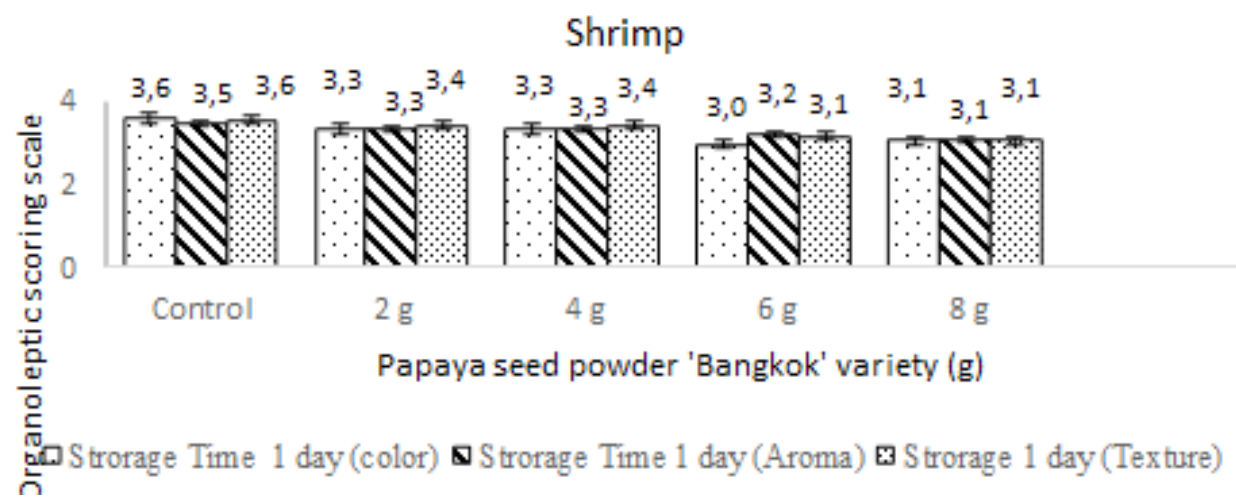

Figure 5. Organoleptic of papaya seed powder variety of 'Bangkok' in shrimp for one day of storage

\section{Shrimp}

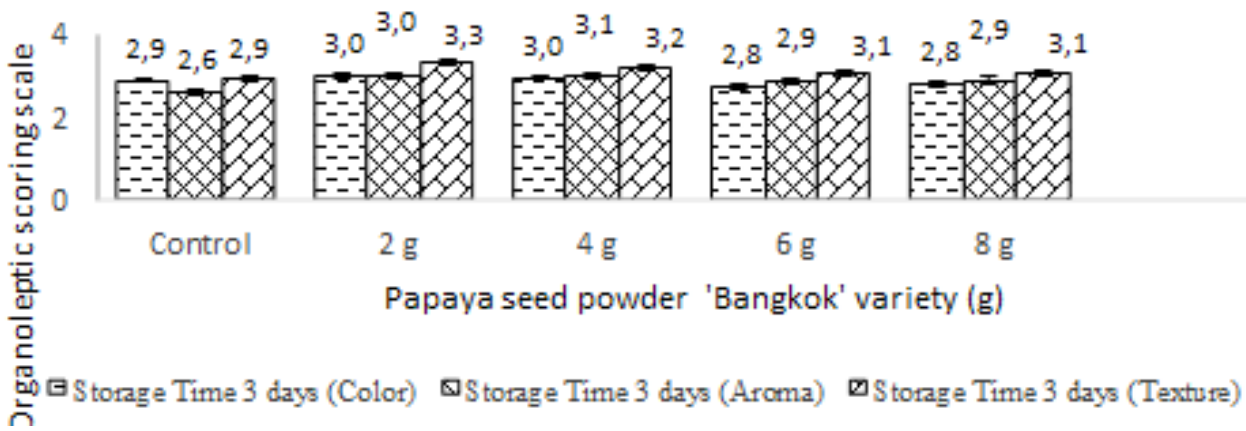

Figure 6. Organoleptic papaya seed powder variety of 'Bangkok'in shrimp for three days of storage

\section{Shrimp}

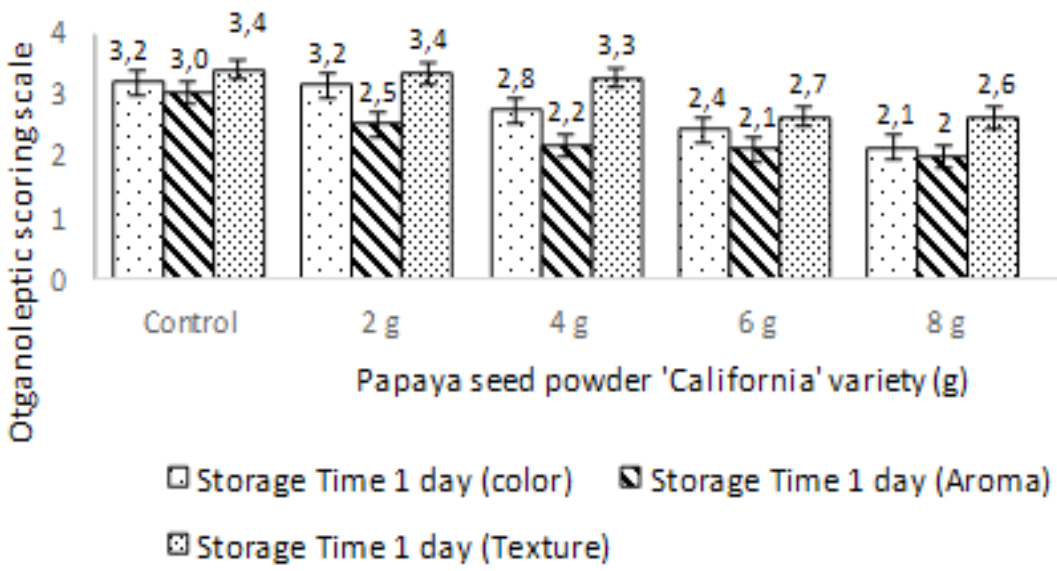

Figure 7. Organoleptic papaya seed powder variety of 'California' in shrimp for one day of storage 


\section{JURNAL BIDDJATI}

http://journal.uinsgd.ac.id/index.php/biodjati

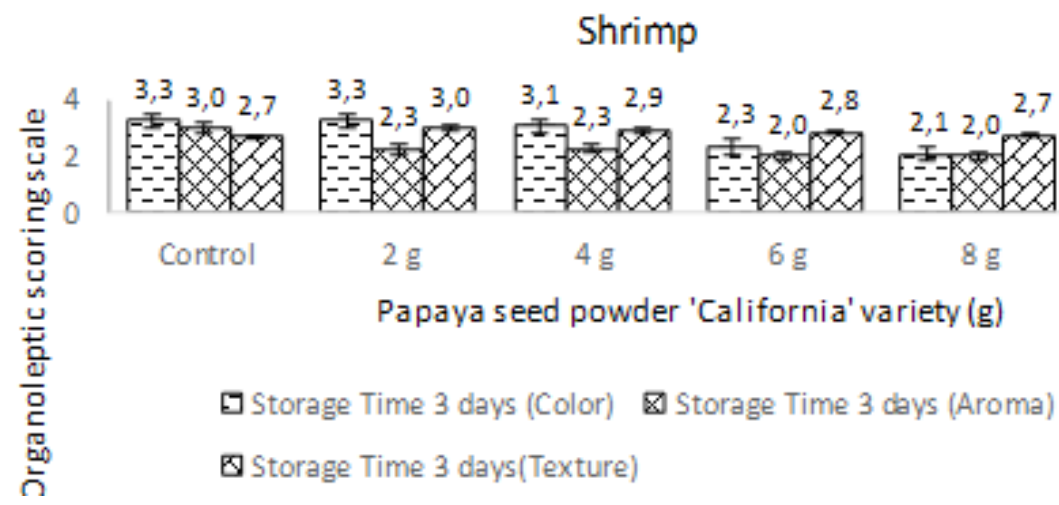

Figure 8. Organoleptic papaya seed powder variety of 'California' in shrimp for three days of storage

According to Soeparno (2009), the changes in meat color is affected by oxygen exposure, $\mathrm{pH}$, and water content. A decrease in organoleptic appearance showed that there was decay during storage. Based on the research of Karnila et al. (2006). The pre rigor stage of giant prawns (Macrobachium rosenbergii) lasted for 2.5 hours after it died. It is marked by soft and supple textured meat with a very fresh odor. The organoleptic value of giant prawns at this stage was 8.9 for the rigor mortis stage of giant prawns $(M$. rosembergii) occurring for 6.5 hours starting with muscle lengthening and the body beginning to curve with fresh specific odors. Shrimp organoleptic value at this stage was 7.1 to 8.6, while the post - rigor stage prawn (M. rosembergii) took place at the $12^{\text {th }}$ hour after it dies which characterized by softening of meat, black fluid discharge from its body, and the emergence of reddish spots on the head, legs, and antenna. At this stage, the organoleptic value of shrimp freshness obtained was 5 (Karnila et al., 2006).

Shrimp texture on third day in the control was soft and less elastic. The organoleptic test results of shrimp texture during cold storage will continue to experience a decrease both in preservatives as well as non-preserva- tives. This is because the preservative levels decrease along with storage time at cold temperature. Although the level of elasticity is reduced, the preservative shrimp texture is better because the preservative causes shrimp meat texture more cohesive.

Chicken meat texture is perishable media and suitable for microorganism growth because of its high water content and nutrients, especially protein. Some pathogen microorganisms that commonly contaminate shrimp are Salmonella sp., E. coli, and Staphylococcus sp. They are the main type of microorganisms that can cause the decay in fresh fish.

Papaya seed powder of Bangkok variety contains chemical compounds such as alkaloids group, flavonoids terpenoids, and saturated fatty acids. Papaya seed powder California variety contains chemical compounds such as carboxylic acid group, alkaloids, unsaturated fatty acids, flavonoids terpenoids, steroids and saturated fatty acids, which have antibacterial properties. Extract of papaya seed powder of Bangkok variety is obtained four groups of compounds while from ethanol extract of papaya seed powder of California variety it was obtained seven class of compounds. Papaya seeds contain a class of com- 


\section{JURNAL BIDDJATI}

http://journal.uinsgd.ac.id/index.php/biodjati

pounds that act as antibacterial agents such as alkaloids, terpenoids, flavonoids, steroids, and fatty acids. The antibacterial activity of saturated fatty acids found in plants generally the most effective activity compared to unsaturated fatty acids.

\section{ACKNOWLEDGEMENTS}

Thank you to LP2M UIN Syarif Hidayatullah for providing financial to support for this research, UN.01/KPA/508/2019.

\section{REFERENCES}

Aberle, E. D., Forrest, J. C., Gerrard D. E., Mills, E. W., Hedrick, H. B., Judge, M. D. \& Merkel, R. A. (2001). Principles of Meat Science. 4 th Ed. Dubuque, Iowa: Kendall/Hunt Publishing Co. .

Agustini, T., Dewi, E. N., Sumardianto, E., Susanto, H., Prayitno. \& Kurniawan, F. W. (2007). Kajian penggunaan bahan alami pada ikan bandeng segar. Jurnal Sains dan Teknologi Perikanan 9 (2) : 123-133.

Badan Standardisasi Nasional (BSN). (2009). SNI 3924:2009 (SNI mutu karkas dan daging ayam). Retrieved from http://sisni.go.id, 12 Oktober 2019.

Badan Standarisasi Nasional (BSN). (2009). Penentuan kadar total volatil base nitrogen $(T V B N-N)$ dan trimetil amin $n i-$ trogen $(T M A-N)$ pada produk perikanan No. SNI 2354.8.2009. Jakarta: Badan Standarisasi Nasional.

Bahar, B. (2003). Memilih Produk Daging Sapi. Jakarta: PT. Gramedia.

Fellows, P. J. (1992). Food Processing Technology. Ellis Horwood, New York. Padmawinata. Bandung: Institut Teknologi Bandung.

Feng, X., Bansal, N. \& Yang, H. (2016). Fish
Gelatin Combined with Chitosan Coating Inhibits Myofibril Degradation of Golden Pomfret (Trachinotus blochii) Fillet during Cold Storage. Food Chemistry, 200, 283-292.

Fitriani, I. N., Ekaputra, F. \& Hermawan, A. (2006). Sweet Papaya Seed Candy Antibacterial. PELITA, 8(2), 156-163.

Karnila R, Suparmi \& Romaida M. (2006). Kajian Sifat Mutu Udang Galah (Macrobrachim rosenbregii) Segar pada Penyimpanan Suhu Kamar. Jurnal Berkala Perikanan Terubuk, 33(2), 121125.

Kharisma, Y. (2013). Tinjauan Pemanfaatan Tanaman Pepaya dalam Kesehatan. Jurnal Jamu Indonesia, 1(2), 15-19.

Martiasih, Sidharta. \& Atmojo. (2014.) Aktivitas Antibakteri Ekstrak Biji Pepaya (Carica papaya L.) terhadap Escherichia coli dan Streptococus pyogenes. Jurnal Teknologi, 4(1), 5962.

Masduqi A., Munifatul, F. I. \& Erma, P. (2014). Efek Metode Pengeringan Terhadap Kandungan Bahan Kimia dalam Rumput Laut Sargassum polycystrum. Jurnal Anatomi dan Fisiologi, 112(1), 1-9.

Peter, K., Kumar, J. Y., Pandey, P. \& Masih, H. (2014). Antibacterial Activity of Seed and Leaf Extract of Carica papaya Var. Pusa dwarf Linn. Journal of Pharmacy and Biological Sciences, 9(2), 29-37.

Rajesh, M. (2008). Uji Fisik dan Evaluasi Sensoris Menggunakan Tiga Jenis Skala Berbeda pada Produk Brownies Selama Penyimpanan. Skripsi. Fakultas Teknik Pertanian. Universitas Katolik Soegijapranata, Semarang.

Salim, A. N., Sumardianto \& Amalia, U. (2018). Efektivitas Serbuk Simplisia Biji Pepaya sebagai Antibakteri pada 


\section{JURNAL BIDDJATI}

http://journal.uinsgd.ac.id/index.php/biodjati

Udang Putih (Penaeus merguensis) Selama Penyimpanan Dingin. Jurnal Pengolahan Hasil Perikanan Indonesia, 21(2), 188-198.

Sitindaon, J. (2007). Sifat Fisik dan Organoleptik Sosis Frankfurters Daging Kerbau (Bubalus bubalis) dengan Penambahan Khitosan sebagai Pengganti Sodium Tri Polyphosphate (STPP). Skripsi. Program Studi Teknologi Hasil Ternak Fakultas Peternakan Institut Pertanian Bogor, Bogor.

Standar Nasional Indonesia (SNI). (2009). Batas Maksimum Cemaran Mikroba dalam Pangan. SNI 7388:2009. Jakarta: Badan Standardisasi Nasional.

Soeparno. (2009). Ilmu dan Teknologi Daging. Yogyakarta: Gajah Mada University Press.

Suparno, N. S. (2012). Pengolahan udang beku. Kumpulan Hasil-hasil Penelitian Pascapanen Perikanan. Jakarta: Puslitbang Perikanan

Suradi K. (2005). Aplikasi Model Arrhenius untuk Pendugaan Penurunan Masa Simpan Daging Sapi Pada Penyimpanan Suhu Ruang dan Refrigerasi Berdasarkan Nilai TVB dan pH. Jurnal Penelitian SpeSIA, 2(4), 305-308.
Suradi, K. (2008). Perubahan Sifat Fisik Daging Ayam Broiler Post Mortem Selama Penyimpanan Temperatur Ruang. Tesis. Fakultas Peternakan Universitas Padjajaran, Bandung.

Susanto, E., Agustini, T. W., Swastawati, F., Surti, T., Akhmad, S., Fahmi \& Albar, M. F. (2011). Pemanfaatan Bahan Alami Untuk Memperpanjang Umur Simpan Ikan Kembung. Jurnal Perikanan Universitas Diponegoro, 13(2), 60-69.

Taufiq, S., Yuniarti, U. \& Siti, H. (2015). Uji Aktivitas Antibakteri Ekstrak Etanol Biji Buah Pepaya (Carica papaya L.) terhadap Escherichia coli dan Salmonella typhi. Jurnal Penelitian SPeSIA, 5(2), 655-659.

Torar, G. M. J., Lolo, W. A. \& Citraningtyas, G. (2017). Uji Aktivitas Antibakteri Ekstrak Etanol Biji Pepaya (Carica papaya L.) terhadap bakteri Pseudomonas aeruginosa dan Staphylococcus aureus. Jurnal Ilmiah Farmasi, 6(2), 14-22. 